The aggregate duration of employment in the three years reviewed is shown in Table VI. Altogether $17.7 \%$ of referred patients were employed for only $25 \%$ or less of the total timethat is, they were unemployed for $75 \%$ (or more) of the followup period. Hoenig and Hamilton found that $25 \%$ of their patients were unemployed for more than $75 \%$ of their follow-up period, but their case material was limited to those of below retirement age. If those over retirement age are excluded from the present study (two men and nine women) only $6.3 \%$ were unemployed for $75 \%$ or more of the period of follow'up. It should be added, however, that Hoenig and Hamilton did not assess housewives as "employed", whereas in the present investigation if a housewife was actively and regularly engaged in routine housework it was considered more appropriate to include her within the category of the working population, and she was therefore regarded as employed.

TABLE VI-Aggregate Duration of Employment in the 3 Years after Discharge

\begin{tabular}{ccc|c|c|c|c}
\hline \multicolumn{2}{c|}{$\begin{array}{c}\% \text { Time Fully } \\
\text { Employed }\end{array}$} & $\begin{array}{c}\text { No. of } \\
\text { Men }\end{array}$ & $\begin{array}{c}\text { No. of } \\
\text { Women }\end{array}$ & Total & $\begin{array}{c}\% \text { \% of Total Referrals } \\
\text { for Aftercare }\end{array}$ \\
\hline $76-100$ & $\because$ & $\because$ & 15 & 24 & 39 & 40.6 \\
$26-75$ & $\because$ & $\because$ & 14 & 26 & 40 & 41.7 \\
0.25 & $\cdots$ & $\cdots$ & 5 & 12 & 17 & 17.7 \\
\hline
\end{tabular}

\section{Conclusion}

It is considered that the weekly case conference with mental welfare officers and allied personnel was especially helpful in ensuring correct job placement, thereby minimizing subsequent unemployment. As has been stated, “... the clinical psychologist can be extremely helpful in making an assessment of a patient's abilities, measuring progress, and forecasting the type of work suitable for the individual concerned. The occupational therapist and the workshop instructor report on a patient's progress at one of the case conferences, and if the situr: on warrants it the patient can then be referred to the disablement resettlement officer for help in securing a job in the community. By organizing occupational and rehabilitation procedures in this manner it has been found that the need to refer patients to an industrial rehabilitation unit is minimal." With the implementation of the Local Authority Social Services Act 1970 measures of the kind described are likely to prove of increasing importance, especially in relation to supporting and maintaining the more disabled psychiatric patient in the community.

I thank the psychiatric social worker and the mental welfare officers who took part in helping to obtain some of the data for this investigation.

\section{References}

I Silverman, M., British Medical Fournal, 1961, 2, 698.

2 Silverman, M., International fournal of Social Psychiatry, 1965, 11, 204

3 Silverman, M., British fournal of Psychiatry, 1968, 114, 493.

- Sheldon, A., British fournal of Psychiatry, 1964, 110, 662.

- Sheldon, A., British fournal of Psychiatry, 1967, 113, 1009

- Hoenig, J., and Hamilton, M. W., The Desegregation of the Mentally III. London, Routledge and Kegan Paul, 1969.

7 Watson, J. P., Bennett, D. H., and Isaacs, A. D., Lancet, 1970, 1, 511.

8 Brown, G. W., Bone, M., Dalison, B., and Wing, J. K., Schizophrenia and Social Care, London, Oxford University Press, 1966 .

- Silverman, M., British fournal of Social Psychiatry and Communitv Health, 1971,5 , in press.

\title{
Upper Respiratory Tract Infections
}

FROM THE DEPARTMENTS OF THERAPEUTICS AND PHARMACOLOGY, MEDICINE, AND GENERAL PRACTICE, ABERDEEN UNIVERSITY

British Medical fournal, 1971, 1, 101-103

PROFESSOR A. G. MACGREGOR: The management of infections of the upper respiratory tract arouses much controversy, and today we have asked a general practitioner as well as a specialist in chest diseases to join us. Can we get down to the basic contentions right away and discuss the use of antibiotics?

DR. J. G. R. HOWIE: It is very difficult for hospital physicians to discuss this problem authoritatively. There are theoretical reasons for not prescribing antibiotics, but there are strong pressures on the practitioner to do so.

Appointments of Speakers

A. G. MACGREGOR, M.D., F.R.C.P., Professor of Therapeutics and

K. N. V. PALMER, M.D., F.R.C.P., Reader in Medicine

J. G. R. HOWIE, M.D., Lecturer in General Practice

J. C. PETRIE, M.B., M.R.C.P., Lecturer in Therapeutics

R. A. WOOD, B.SC., M.R.C.P.ED., Lecturer in Therapeutics
DR. K. N. V. PALMER: It is important to remember that most upper respiratory tract infections are viral and that most antibiotics have no effects on viruses.

DR. J. C. PETRIE: Upper respiratory infections may be caused by over 100 different viruses. In coryza rhinoviruses are isolated in over half the cases. There are at least 89 serotypes. Parainfluenza viruses are also frequently found. In patients with a sore throat and inflamed pharynx with lymph node enlargement and cough, adenoviruses (and there are at least 34 serotypes), influenza, Coxsackie, and ECHO viruses can usually be isolated.

DR. R. A. WOoD: The behaviour of viruses may be influenced by the age of the patient. For instance, the respiratory syncytial virus may cause a serious bronchiolitis or laryngotracheobronchitis in infants and young children, whereas in adults it usually causes a common cold.

DR. PALMER: Yes, the age of the patient is certainly important. Upper respiratory tract infections are much commoner in the younger age groups and are at a peak when the child 
first goes to school. One must expect these infections at that time and they are not necessarily an indication for the removal of tonsils and adenoids.

PROFESSOR MACGREGOR: I find the terminology in upper respiratory tract infections is rather imprecise.

DR. HOwIE: Yes, the use of a term such as bronchiolitis highlights the problem of the general practitioner. He is dealing with symptoms and signs. The use of pathological terms creates confusion between hospital doctors and practitioners.

PROFESSOR MACGREGOR: This is why we chose to talk about upper respiratory tract infection-not about specific syndromes. Could we return to the argument that seems to centre on the fact that viruses are usually the cause of upper respiratory infections but practitioners very frequently prescribe antibiotics?

\section{Use of Antibiotics}

STUDENT: Is this justified, particularly as the virus infection is unlikely to be influenced?

DR. WOoD: Many doctors believe that the severity and duration of the illness is reduced if they prescribe antibiotics. They concede that bacteria do not cause the primary upper respiratory infection but feel that antibiotics reduce the incidence of significant secondary bacterial invasion particularly with the pneumococcus and Haemophilus influenzae.

DR. HOWIE: The patient is usually seen in general practice at an early stage in his illness and the practitioner has to judge the probable evolution of the infection. He usually prefers to avoid the risk of the development of complications and his patients appreciate this.

DR. PETRIE: I have sympathy with the practitioner. There are considerable pressures to prescribe an antibiotic for a patient who has an inflamed throat and tender lymph nodes. The patient often expects, and even may ask for, an antibiotic.

DR. HOWIE: Perhaps younger doctors have not had the opportunity to learn the natural history of untreated minor respiratory illness and, consequently, may in good faith overestimate the risk of a serious complication developing in a moderately well child.

PROFESSOR MACGREGOR: Much bacteriological and viral investigative work has been done and the theoretical advice is not to prescribe antibiotics as most infections are viral. Even so, many practitioners feel that this kind of theoretical advice has little relevance to the conditions under which they see the patient. Unfortunately there have been few clinical studies in this field.

DR. HOWIE: That is the point. We just don't have the profit and loss accounts of the use and non-use of antibiotics in upper respiratory tract infections. If there were clear guide-lines practitioners could confidently withhold antibiotics but at present, in general, they are uncertain.

DR. WOOD: It is my impression that the practitioner is in a unique position to spot epidemics of highly virulent organisms.

DR. HOWIE: I am not so sure. Personally, I find it very difficult to judge the virulence of a particular epidemic as the number of patients one doctor sees in one practice is fairly limited. Until there is evidence on a community basis a decision to treat or not to treat will be made on a rather hit or miss basis.

\section{Place of Bacteriology}

STUDENT: Should throat and pharyngeal swabs not be done routinely?

DR. WOOD: Certainly not. If the millions of patients who develop upper respiratory infections annually were swabbed routinely the bacteriology laboratories would be overwhelmed and the yield would be low. Besides, we have emphasized that most infections are viral.

DR. PETRIE: Identifying a particular virus is rather difficult, time consuming, and also rather unrewarding. There are difficulties in collecting, storing, and transporting samples for subsequent viral studies. A recent development which may allow more rapid identification of viruses is the fluorescent antibody technique.

PROFESSOR MACGREGOR: It is most important that significant bacterial infection is not missed in special risk groups.

DR. PALMER: I would also stress that point. In patients with a history of rheumatic fever, or who have a family history of rheumatic fever, or have had nephritis, the presence of a group A beta-haemolytic streptococcus must be detected. These are "special risk" patients.

STUDENT: Is it not easy to differentiate a streptococcal throat infection from a viral one?

DR. PALMER: I am glad that you have brought that point up. I certainly can't tell the difference and most doctors agree that it is impossible. In "special risk" patients a throat swab and preferably an antistreptolysin titre should be obtained. A bactericidal drug, such as penicillin, should be given for a full ten days to eradicate infection. I like to confirm that this has been achieved with a negative throat swab a few days after chemotheraphy has been stopped.

PROFESSOR MACGREGOR: Throat swabs should also be done in children in any epidemic where a virulent streptococcus has been implicated. The more serious the infection the more likely it is that complications may follow.

DR. PALMER: Can I stress two points ? Firstly, young patients who have had rheumatic fever must have continuous bactericidal chemoprophylaxis at least until five years after leaving school, and preferably until the age of 21 . The best way of giving penicillin is by monthly injection of the long-acting benzathine penicillin in a dose of $900 \mathrm{mg}$ ( 1.5 megaunits).

DR. PETRIE: The intramuscular route ensures that the drug is taken and has been shown to be superior to oral penicillin in this group of patients. It has been said the chemoprophylaxis should be continued for life.

DR. PALMER: The other point in patients who have had rheumatic fever is that when having dental extractions penicillin must be given two to three hours before the extraction, ideally by injection. The penicillin should be continued by the oral route for 24-48 hours.

STUDENT: It is said that not giving penicillin to patients with haemolytic streptococci may allow antibodies to develop which persist for several years.

DR. WOOD: This is a dangerous philosophy; it is the antibodies which cause rheumatic fever and glomerular nephritis.

PROFESSOR MACGREGOR: I prefer to treat these "special risk" patients energetically and not to take any chances. 


\section{Children with "Asthma"}

DR. HOWIE: I am often concerned when young children with so-called "asthma" develop upper respiratory tract infections.

DR. PALMER: I agree that these children and the so-called "catarrhal" child pose problems. They wheeze readily when they have acute respiratory infections because the bronchi are small in calibre and sputum retention and mucosal oedema readily lead to obstruction in these small airways. Wheezing in these young children does not necessarily mean that they have asthma. If the child is still wheezing when he has an upper respiratory infection as he grows older-say, 8-10 years-then the aetiology is more likely to be allergic.

DR. WOoD: If there is eczema, or an atopic history, or a family history of hay fever or eczema, this is a helpful guide.

DR. PETRIE: Another group of patients who have a similar predisposition to significant bacterial invasion are patients who have lower respiratory tract disease, where the upper respiratory tract infection may be the trigger for an acute bacterial exacerbation.

DR. WOOD: The same applies to patients who have a history of otitis media or sinusitis. These patients should have the appropriate swabs carried out and significant bacterial invasion must not be missed.

\section{STUDENT: Which bacteria are important ?}

PROFESSOR MACGREGCR: Pneumococcus is most often implicated. Penicillin is the drug of first choice. We use penicillin V in a dose of $250 \mathrm{mg}$ four times daily for seven days.

STUDENT: I have seen erythromycin and lincomycin used.

DR. PETRIE: The specific indication for the use of erythromycin against the pneumococcus is in a patient who is allergic to the penicillin group of drugs. Though very effective against the pneumococcus, it has the disadvantage that organisms do develop resistance to it rather rapidly. We keep it as a reserve drug.

DR. WooD: Lincomycin is not superior to penicillin or erythromycin against the pneumococcus and is more expensive. It is also indicated in patients who are allergic to pen cillin but it does cause gastrointestinal upsets. A new preparation, clindamycin, is better absorbed and is claimed to cause less gastrointestinal upsets but again is expensive.

DR. HOWIE: We have recently carried out an extensive work load study in the North East of Scotland and erythromycin was used in $4 \%$ of antibiotic prescriptions for respiratory tract infection. Individual doctors ranged in their usage of erythromycin from $0-51 \%$ of prescriptions.

\section{Antibiotics in General Practice}

STUDENT: Do practitioners give antibiotics to save having to see their patients again? I have heard it said that this might reduce night calls and return visits.

DR. HOWIE: In the work load study there was no evidence that doctors who frequently prescribe antibiotics differ in the rate of return consultations from low users of antibiotics. But your point might be valid in an epidemic.

DR. PETRIE: What is the prescribing pattern for tonsillitis in general practice? It must surely depend on the definition of the "disease".

DR. HOWIE: Our study also showed that tonsillitis was diagnosed by different doctors at rates varying from 1 to $47 \%$ of respiratory tract infections. The term is clearly too imprecise, and I can assure you that the situation is even worse for less objective diagnosis. This emphasizes once again the difficulty of applying the principles of hospital medicine to general practice. We must now define precise descriptive terms for the common groups of presenting symptoms rather than guess at pathological processes.

PROFESSOR MACGREGOR: Obviously, there is much fascinating work to be done. Can you tell us if prescribing patterns for antibiotics are consistent between doctors in the management of respiratory tract infection?

DR. HOWIE: Our work has shown an overwhelming trend to use penicillin for so-called tonsillitis. Most doctors do not use tetracycline in children under 7 years of age, in contrast to a few doctors who use it frequently. The latter are clearly out of step, not only with hospital medicine but also with their own colleagues in their own specialty.

DR. wooD: Apparently, there are still some doctors who are unaware that when tetracycline is given to pregnant women or to children it causes enamel hypoplasia and discolouration of children's teeth. There may also be impairment of bone growth, as tetracycline is deposited in the bone because of a chelating effect.

PROFESSOR MACGREGOR: I would have to have an exceptional reason to prescribe tetracycline to a pregnant woman or to a child under the age of 7 years.

DR. PALMER: A recent paper has shown that there was no apparent benefit from giving tetracycline to previously healthy adult patients when they developed influenza.* This is a most important contribution to our knowledge about respiratory infections. I hope this goes some way to influencing prescribing patterns.

PROFESSOR MACGREGOR: My sympathies lie with the general practitioner, who is really in a most difficult position. Theoretically in most cases he need not give the antibiotic, but I agree that there are many pressures.

DR. PETRIE: Unfortunately it is not just doctors who expose patients to antibiotics. Antioiotics are used in preserving foodstuffs and also to promote animal growth. There is evidence that the prognosis for staphylococcal infections is getting worse because of the increasing number of staphylococci which are resistant to different drugs.

DR. HOwIE: I think most practitioners would agree that they would like to use fewer antibiotics.

PROFESSOR MACGREGOR: What else should be done in the management of upper respiratory tract infections?

DR. PALMER: The management is based on simple measures. If the patient is febrile he should stay in bed. Even if he is afebrile he should stay at home and thereby reduce the spread of infection. Inhalation of steam and frequent hot drinks are helpful. Fever and headache may be relieved by an analgesic such as aspirin or paracetamol. He should not smoke, and infections such as this are a good point for smokers to start giving it up.

PROFESSOR MACGREGOR: There is no disagreement about the importance of these simple measures. In summary, most upper respiratory tract infections are viral and antibiotics are seldom indicated for the initial management. It is particularly important in "special risk" groups to identify and eliminate significant bacterial invasion. We fully appreciate the problems of the general practitioner, who must look for these "special risk" groups. Obviously active and realistic research is going on in this field and we all look forward to the results.

* Howie, J. G. R., and Clark, G. A., Lancet, 1970, 2, 1099. 